\title{
Recent Work on the Results of Fertilization in Angiosperms.
}

BY

\section{ETHEL SARGANT.}

$\mathrm{HE}$ main conclusions drawn by Nawaschin (6) from his
recent researches on the fertilization of Lilium Martagon and Fritillaria tenella were published in Russia more than two years ago. They were first brought to the notice of most European botanists by a paragraph in the Botanisches Centralblatt of January 4, I899 (6), and this was shortly followed by the publication of similar results by Guignard (3). These results, obtained by independent observations on material almost identical, formed the most complete and striking confirmation of Nawaschin's work. Both botanists had examined the embryo-sac of Lilium Martagon-the classic ground for such observations-and both had come to the startling conclusion, with which we are now familiar, that the pollen-tube sets two generative nuclei free in the embryosac, one of which fuses with the nucleus of the egg-cell, the other with that which we are accustomed to call the definitive nucleus of the embryo-sac. This definitive nucleus is itself a compound structure, formed by the fusion of the polar nuclei. In Lilium Martagon the generative nucleus sometimes reaches the polar nuclei before they have met, sometimes afterwards, but in either case the nuclear fusion in the 
centre of the embryo-sac is clearly seen to be a fusion of three nuclei, not two.

The same phenomena were observed by Nawaschin in Fritillaria tenella and by Guignard in other species of Lilium (L. pyrenaicum, \&c.). Botanists were therefore presented almost simultaneously with two independent sets of concordant observations made by two observers of the first rank on a few closely allied species. So unlooked-for were their results, that evidence less irresistible than this might well have needed confirmation. As it was, the facts were generally accepted at once (Strasburger, 10), and became the startingpoint for further research. This has now proceeded for over a year in more than one direction.

As facts have accumulated, the question of their theoretical importance has become more pressing, and we have now several conflicting opinions on the subject. I propose in this paper to collect together, so far as is possible, all the work which has followed the original discovery, and to consider its bearing on the theoretical considerations involved. Such an attempt in these early days can have at the best no permanent value. But it is sometimes useful in the early stages of an investigation to take stock, as it were, of our assets of knowledge. This is more particularly the case when the subject is of general interest, and the work done in it is scattered through a number of memoirs by specialists. Much of this work has already been collected by Strasburger (11) in his recent important paper in the Botanische Zeitung, to which I shall have occasion to refer again.

Four distinct questions were suggested by the discovery of 'double fertilization 1'. They may be briefly stated as follows :-

I. Is the phenomenon of double fertilization general among Angiosperms, or to be considered as peculiar to a few species?

2. Does the twisted (vermiform) shape of both generative nuclei in Lilium indicate that they have an independent power

1 The expression 'double fertilization' is used for convenience throughout this paper, and is not intended to imply any view as to the nature of the conjugation. 
of motion within the embryo-sac, and if so, can they be considered as much reduced spermatozoids?

3. What light is thrown by these researches on the homology of the structures contained in the typical embryo-sac of Angiosperms?

4. Can the fusion of the second generative nucleus with the definitive nucleus of the embryo-sac be considered as a true act of fertilization?

It will be convenient to deal with these questions separately, and to consider the work of the past two years with reference to each in turn, rather than to adopt a strictly chronological arrangement. I shall also mention in connexion with each any work of an earlier date which seems to me to bear on the point, or to suggest an opening for further research.

\section{Occurrence of Double Fertilization \\ In Angiosperms.}

Considering that we are dealing with the work published during little more than a year, and that the labour involved in such research is great, the number of species in which double fertilization has been observed since the original discovery may be called large. The following is a list; as complete as I can make it, up to the present date (Nov. I4, I900). It includes the original observations on Lilium. For convenience of reference the specific name used by the observer is retained.

ORDER.

Liliaceae

Species.

OBSERVER.

Monocotyledones.

Lilium Martagon.

L. pyrenaicum

Fritillaria tenella.

F. Meleagris.

Tulepa Gesneriana.

T. Celsiana.

T. sylvestris.

Endymion nutans.
Nawaschin.

Guignard.

Guignard.

Nawaschin.

Guignard.

Guignard.

Guignard.

Guignard.

Guignard. 
ORDER.

Orchidaceae

\author{
Arundina speciosa. \\ Phajus Bhumei \\ Phajus sp. \\ Himantoglossum hircinum. \\ Orchis latifolia. \\ 0. maculata. \\ O. mascula var. Hortii.
}

Dicotyledones.

Ranunculaceae

Compositae

$$
\begin{aligned}
& \text { Caltha palustris. } \\
& \text { Delphinium elatum. }
\end{aligned}
$$

Helianthus annuus.

Rudbeckia speciosa.

Monotropeae

Monotropa Hypopitys.

Nawaschin.

Nawaschin.

Nawaschin.

Strasburger.

Strasburger.

Strasburger.

Strasburger.

\section{Thomas.}

Nawaschin.

Nawaschin.

Nawaschin.

Strasburger.

The total number of species in which double fertilization has been recorded is thus twenty. These twenty species represent twelve genera (if Himantoglossum be included with Orchis), and five orders, three of which are Dicotyledonous.

Before we can properly estimate the collective value of the evidence, the difficulties of this branch of research must be considered. Material can be collected only in the flowering season. Excluding the four species observed before I 899, and the four collected and observed by Strasburger in 1900, we have twelve species belonging to nine genera, and representing four families - two of them Dicotyledonous-as the result of one season's pickling by three observers. The material for such work must be chosen from plants which are known to seed freely. The flowers must commonly be collected at least twice a day for two or three successive days, in order to secure the right stage, and each picking must be kept separate from the others throughout all the processes of the elaborate fixing methods, which are necessary in order to secure adequate preservation of the embryo-sac. When observation of material thus collected and preserved begins, 
the preliminary work of cutting ovaries of different ages, and looking over the series of sections to determine which contain embryo-sacs at the exact point of development, is in itself heavy. Outside the Liliaceae and their allies se rarely find ovules arranged in rouleaux, and must sometimes sacrifice a whole ovary to secure median sections of a single ovule. Nor are adjacent ovules necessarily in the same phase of growth: fertilized and unfertilized are found in the same ovary, and among the fertilized some are too young and some too old for our purpose. In many cases it is essential to work with microtome sections only: in all they must be used to determine the minute structure with precision. But there are disadvantages in sections so thin as those of microtome series. The embryo-sac is commonly cut into many slices, of which each must be observed with a very high power, and the solid body mentally reconstructed from the succession of layers. The labour of thus observing a number of embryosacs, the sections of which are found in groups among long series of useless sections extending over many separate slides, and of indexing them in order to record such observations, can hardly be exaggerated.

Nor is the interpretation of results without difficulty. In some of these species the generative nuclei do not show the vermiform shape which makes it easy to distinguish them from the other nuclei in the embryo-sac. This is the case, for example, in Endymion mutans (Guignard, 4). Both the generative nuclei in this plant are small and egg-shaped. In some species, too, the polar nuclei are completely fused into one by the time the pollen-tube enters the embryo-sac. Now in plants which combine these features the identification of the second generative nucleus must of necessity be laborious. In the first place, a number of preparations from an earlier stage of development will be required to show that the fusion of the polar nuclei is commonly complete before the entrance of the pollen-tube. Even when this is established, a single preparation showing the fusion of two similar nuclei in the centre of an embryo-sac, which also contains a fertilized egg- 


\section{Sargant.-Recent Work on the Results}

cell, is not by itself conclusive, for there is always the possibility that the polar fusion may have been retarded in any one instance. We require either a large number of such preparations to establish a strong probability that one of the fusing nuclei is generative, or several instances in which both generative nuclei are free in the embryo-sac, each approaching its proper goal. For before conjugation the generative nuclei can commonly be distinguished from those surrounding them by their smaller size and deeper stain. But such preparations are exceedingly rare: the passage of the generative nuclei from the pollen-tube to the nuclei with which they are to fuse must be tolerably rapid, for they are seldom caught on the way. Thus it may easily happen that thousands of sections must be passed in review, and hundreds carefully examined under a high power, before the point in question is finally determined.

Such difficulties may be prohibitive, and hence they greatly limit the choice of material. It is not surprising that in some cases only negative results have been reached (Merrel on Silphium, 31). Rather we may conclude that the number of widely-separated species in which double fertilization has been observed in so short a time, affords strong evidence that the process is general among Angiosperms which show the usual structure of the embryo-sac before fertilization. I think we are justified in assuming its existence in any such embryosac as a working hypothesis until we have the opportunity of settling the question by direct observation, and that the negative evidence must be very strong which should lead us to doubt it.

\section{Movement of the Generative Nuclei.}

The elongated and twisted shape of both generative nuclei in the embryo-sac of Lilium Martagon suggested to the original observers the arrest of automatic movements by the action of the fixing agent. This led to comparison with the newly discovered spermatozoids of Cycas (Ikeno, 25, 26), 
Ginkgo (Hirase, 24), and Zamia (Webber, 41, 42, 43), and the generative nuclei were represented as much reduced spermatozoids, the existence of which formed a fresh phylogenetic link between the Cycadeae and Angiospermae. This hypothesis has been discredited by later work. The absence of cilia could be explained away so long as the vermiform nuclei had not been seen outside the embryo-sac, for Guignard pointed out $(5$, p. 375) that the cilia of antherozoids disappear as soon as they enter the archegonium. But in Silphium (Merrel, 31, p. II3, Fig. 6I) the elongated male nuclei have been observed in the pollen-grain without any trace of cilia. Moreover, the small quantity of cytoplasm which enters the embryo-sac with each generative nucleus is in some cases at least quite undifferentiated (Guignard, 5, p. 375, Figs. I4, I6, I8), Guignard himself has shown that in Endymion mutans (4, p. I95, Figs. 21, 22, 23) the generative nuclei do not assume the vermiform shape. Thus in a plant so nearly allied to Lilium as this, the only character which suggested automatic motion is absent, and this fact in itself affords a strong reason for attaching no phylogenetic importance to the shape of the nuclei.

Finally, Strasburger has once again followed the whole process of fertilization in the living ovule of Monotropa. His results, so far as they affect our point, are briefly these. The polar nuclei are connected with the egg-apparatus and with the antipodal cells by thick strands of cytoplasm which are in constant streaming movement. The contents of the pollentube when discharged reach down to the egg-apparatus. One generative nucleus can be identified as soon as it touches the nucleus of the egg-cell. The other cannot be distinguished with certainty until it has been in contact with the central nucleus of the embryo-sac for some time. But it is almost certainly carried down by the current in the strand which joins the egg-apparatus to the central nucleus, and a swelling in this strand probably indicates its passage. Fixed and stained preparations confirm these observations. Both generative nuclei can be recognized in such preparations from the 
time they leave the pollen-tube. In shape they are ovoid as in Endymion (Strasburger, 11, pp. 298-301).

On the other hand Nawaschin $(8$, p. 228 , Fig. I) has shown that the generative nuclei in the embryo-sac of Helianthusand to a less marked degree those of Rudbeckia-are shaped like a corkscrew, and their appearance does strongly suggest that they possess the power of independent motion.

From the sum of these observations we may conclude that possibly the generative nuclei in some species of Angiosperms may make their own way through the embryo-sac to the nuclei at which they aim, but that in others this passage is almost certainly effected by the streaming motion of the cytoplasm in the embryo-sac, which carries the nuclei passively with it. If this be so, the power of automatic movement would seem to be an adaptive character, assumed or laid aside by the generative nuclei according to circumstances. These nuclei are indeed homologous with the nuclei contained in the spermatozoids of Vascular Cryptogams and Cycads, but they do not appear to be accompanied by any vestiges of the differentiated cytoplasmic structure characteristic of those bodies.

If we call the generative nuclei of Helianthus, for example, spermatozoids or antherozoids, we imply that the differentiated cytoplasmic element in such structures is not essential. This amounts to re-defining the terms, a serious step to take in order to emphasize a phylogenetic theory which is, to say the least, very doubtful. If we extend either term to include such non-motile nuclei as those of Monotropa, and probably those of Endymion, Tulipa, and others, we further give up the character of automatic motion, and it is difficult to see what is retained to distinguish a spermatozoid from a male cell or even from a male generative nucleus. This applies equally to the spermatia of Florideae (Guignard, 4, pp. 375-6 footnote).

III. Homology of the Embryo-SAC AND its Contents.

One of the greatest gaps in our knowledge of vegetable morphology lies in our ignorance of the pedigree of Angio- 
sperms. We have no series of forms to link the structures produced within the embryo-sac of such a plant as Lilium Martagon with those derived from the macrospore of the higher Cryptogams. The connexion of the Gymnosperms with the Vascular Cryptogams can be traced in their gametophytes. But though the ancient and very distinct groups included under the general term Gymnosperms are in some sense intermediate between Vascular Cryptogams and Angiosperms, yet our knowledge of embryo-sac structure in anomalous Angiosperms is so incomplete that we can hardly do more than hazard a guess as to whether any particular deviation from the best-known type is to be considered a specialized, a reduced, or a primitive form. Thus the attempt to derive Angiosperms from one or more primitive forms related to one or more groups of existing Cryptogams must be made at present without the aid of independent evidence as to the origin and progressive reduction of the Angiospermous gametophyte. But this is the very class of evidence which has been found most valuable in tracing the origin of any group of Gymnosperms, for example, from some 'generalized' form of Vascular Cryptogam. The gametophyte of some species of Gnetum is little less reduced than that of the typical Angiosperm. But the work of Karsten (28) and Lotsy (30) enables us to trace its reduction step by step through the successive forms of Gnetum Gnemon, Welwitschia, Ephedra, from a massive tissue such as that found in Cycas or the Coniferae. From that point the connexion with the prothallus of the higher Cryptogams is clear.

Until some causeway such as this has been built up stone by stone to connect the Angiosperms with their neighbours, all theories as to the race-history of the structures contained in the embryo-sac of Lilium - to take the classical examplemust be considered as at best working hypotheses, useful indeed to stimulate and direct research, but without authority, and in their very nature tentative.

Without such hypotheses research could not proceed. Where two or more explanations of the same facts are equally 
possible, the attention of the investigator is led to critical observations which may decide between them. His powers are directed to clearing up certain obscure points one after the other, and so step by step he wins his way to the truth. But any one of these explanations, if received too hastily as representing facts, will be fatal to research. Each may become the watchword of a school, and arouse fruitless controversy. It is therefore with no idea of coming to any decision in favour of one view rather than another that I propose to discuss the suggestions already made as to the homologies of the cells derived from the Angiospermous embryo-sac. I would rather ask what line of research is suggested by the work of the last decade in this direction, and in particular what change in theoretical conceptions has arisen from the discovery of double fertilization.

We have recently been learning by degrees that the structure of the embryo-sac in Angiosperms is by no means so uniform either before or after fertilization as botanists were once apt to believe. Some of these variations are undoubtedly derived from the more usual structure, and are specialized for some particular end, rather than primitive. Thus the persistence and occasional division of the antipodal cells in Nigella sativa described by Westermaier $(44$, p. 8$)$, is probably due, as he suggested, to their function in this plant as transmitters of food material. But it would be very rash in the absence of further evidence to assume that the multiplication of antipodal nuclei in the embryo-sac of Sparganium simplex (Campbell, 19, 20), must be referred to a similar cause. Westermaier himself has described a growth of 'antipodal tissue' in Zea Mays and other Grasses before fertilization. In Sparganium, and perhaps in Zea also, the multiplication of cells within the embryo-sac cannot but suggest the formation of a prothallus. Whether this suggestion is justified can be determined only by extended research.

The antipodal cells have been considered as representing (a) the vegetative part of the prothallus, (b) a second eggapparatus, and $(c)$ that part of a monoecious prothallus which 
produces the male elements. This last view is implied in Le Monnier's explanation of the fusion of the polar nuclei as a sexual act (see Groom, 22, p. I33). The upper polar nucleus must, as the sister of the egg-nucleus, represent the female element in the conjugation. The lower polar nucleus must therefore represent the male element. But this assumption is no longer necessary, as we now know that there is a triple fusion, in which the second generative nucleus supplies the male element. Thus the third suggestion $(c)$ has been shelved, and we are left with two.

There is nothing in the discovery of double fertilization to decide between the two views which remain. Future research may reveal a chain of forms linking the whole structure of the embryo-sac before fertilization with some more primitive type in which the homologies with lower plants are clear. Many species are known in which the antipodals increase in number. For references to the literature of the subject I must refer to Strasburger's paper (11, p. 3II). As suggested above, there is no reason to suppose that all these forms are adaptive because some are so.

The discovery of double fertilization has, however, a direct bearing on the vexed question of the origin of the Angiospermous endosperm. This tissue was considered by Hofmeister to represent a prothallus, the development of which was arrested before fertilization. The fusion of the two polar nuclei which takes place about the same time as the fertilization of the egg-cell gave the signal for renewed development. This view held its ground for a generation, and gave rise to the accepted nomenclature. The food-tissue formed by Gymnosperms within the embryo-sac before fertilization, which undoubtedly represents the female prothallus, is generally called the endosperm to mark its supposed homology with the tissue we are now considering in Angiosperms. Strasburger (11)-himself a supporter of the classical view-has justly remarked (p. 3I4) that the true issues would be rendered clearer if we called the Gymnospermous tissue a prothallus, and confined the term endosperm to Angiosperms. This is a 
very welcome suggestion, and I hope it will find favour with botanists.

Le Monnier (29), on the other hand, suggested in 1887 that the fusion of the polar nuclei ought to be considered as an act of fertilization, and the tissue derived from it as a second embryo modified to serve as a food-tissue for the embryo regularly derived from the fertilized egg-cell.

The fact that a generative nucleus takes part in the formation of the original endosperm-nucleus certainly strengthens the view that this nucleus is formed by an act of fertilization. Whether the tissue derived from its repeated division is morphologically a second embryo or not is a question of race-history. It must be settled by purely morphological evidence-by the search for intermediate forms, which may either give some conception of the stages through which such a twin-formation passed before it assumed its present aspect, or may link the endosperm with a reduced prothallus. Treub (40, p. I94) has given good reason for supposing that a considerable number of nuclei are formed in the embryo-sac of Casuarina before fertilization. It is of the first importance that we should know the details of the process of fertilization in this genus. Unfortunately the difficulties of observation are great (Treub, 40, p. I99). They may possibly be overcome by the application of the most recent fixing and staining methods.

In Peperomia, Johnson (27) has found a fusion of six nuclei to form the primary endosperm nucleus. His work and that of Campbell (21) is discussed by Strasburger, who is inclined to consider the structure of this embryo-sac as derived from the normal structure rather than as primitive. The examination of more allied forms might throw light on the question.

The embryo-sac of the Amentiferae shows the usual arrangement of nuclei before fertilization. (Nawaschin, 33, 34, 35,36 , and Benson, 17). Much in the development of the embryo-sac, however, shows a primitive structure, and it would be very desirable to have fuller details of the act of fertilization itself.

Strasburger (11, p. 310) has suggested that the Angiosperms 
postpone the formation of an endosperm until fertilization is accomplished in order to avoid the waste of material which must occur if this massive tissue were thrown off by the plant with every unfertilized ovule. This is a very probable explanation, but it does not affect the morphological question at all. For the plant in need of a food-tissue, to be formed after fertilization, is as capable of adapting a modified second embryo to that purpose as of postponing the formation of a prothallus. In the latter case indeed the expedient of a second conjugation to stimulate development appears cumbrous. In some species of Gnetum (Gn. Rumphianum and Gn. ovalifolium, Karsten 28), the formation of a prothallus begins before fertilization, is checked for a time, and proceeds after fertilization, without any fusion between a generative and a prothallial nucleus. Both generative nuclei in fact conjugate with egg-nuclei, and form two rudimentary embryos. Here the stimulus which excites the prothallus to renewed activity must be carried in some other way.

In short, the problem from the morphological point of view is this. We have to account historically for the endosperm of Angiosperms. If it arose from a belated formation of - prothallus, we must trace the origin of the triple nuclear fusion which precedes its development. Such a fusion is an interpolation in the history of the prothallus which needs explanation. If, on the other hand, the endosperm is a modified embryo, derived from a fertilized egg-cell, we have to account for the interference of the lower polar nucleus with the act of fertilization, and for the subsequent development of a body unlike a normal embryo.

As regards the last point it is perhaps worth notice that the common mode of endosperm-formation among Angiosperms recalls that of the pro-embryo in Cycas circinalis (Treub, 39, p. 5, figs. 9, I2, I3, P1. I) and Stangeria paradoxa (Lang, 28 a, p. 293). That the pro-embryo is formed within an archegonium, and the endosperm within the embryo-sac, is of less importance than appears at first, for the archegonium is completely suppressed among Angiosperms. 
iV. Nature of the Triple Nuclear Fusion.

The fourth and last question to be dealt with is whether the fusion of the second generative nucleus with the two polar nuclei can be considered as a true act of fertilization.

The expression fertilization may be used in an abstract or a concrete sense. In the abstract it denotes the process by which characters from two individuals are transmitted to a single organism in the succeeding generation. This phenomenon is almost universal throughout the animal and vegetable kingdoms, and its effects have been observed by many successive generations of breeders both of animals and of plants. In this way a considerable body of evidence has accumulated, and it has been found that certain laws are universally true of organisms which thus spring from a double stock. Such an organism passes through its complete lifehistory, which may include more than one cycle of development. It exhibits a combination of characters drawn from both parents. The offspring of the same pair differ from each other: some resemble one parent, some the other, and those of mixed appearance may lean to either side. But a balance is maintained in each generation between the two stocks, so that neither parent has on the whole greater weight than the other.

Two features may be commonly distinguished in the abstract conception of the process of fertilization : the union of the characters of both parents, at the same time that a certain balance is maintained between them, and the impulse to further development impressed on members of the younger generation (Strasburger, 11, pp. 304-6; R. Hertwig, $23 a$, p. 149). The combination and balance of parental qualities has been happily called ' amphimixis' by Weismann (45, pp. 20 and 232 ).

In many unicellular organisms, no special stimulus to development seems to accompany the act of conjugation (Weismann, 45, p. 232; R. Hertwig, 23 a, p. 146). But among the higher plants, with which alone we are concerned at 
present, a double process is included under the general term fertilization. Characters from both parents are transferred to the offspring by amphimixis, and the development of the fertilized egg-cell is secured by the presence of a growthstimulus.

If we now inquire into the machinery by which these results are attained, we find that the act of fertilization is remarkably uniform in all organized beings. It consists in a fusion of two cells to form a new one, which then divides and ultimately gives rise to an individual whose characters are intermediate between those of its parents. This is fertilization in the concrete sense. Its phenomena supply a material basis for the general laws of heredity to which I have just referred.

When the act of fertilization is studied in detail, certain features are found to be general. The male cell is usually small, and the nucleus forms the most considerable part of it. The cytoplasmic elements are greatly reduced. When the male and female cells fuse, the union of their nuclei is the most characteristic feature of the process. Both are generally in the resting state at the time of fusion, but though they commonly unite in that condition so far as to enclose a single cavity, yet it very often happens that fusion is not complete until the first karyokinesis has taken place ${ }^{1}$. The male and female chromosomes can frequently be distinguished in the equatorial plate, and it is not until a segment of each has travelled to either pole, and the daughter-nuclei are in process of construction, that the chromatic elements from the male and female nuclei are really united. Boveri (18) does not consider the act of fertilization complete until the first karyokinesis after conjugation is accomplished (p. 416). There is a double advantage in adopting this view. We are secure that the chromatin-fusion has actually taken place, and the occurrence of the first division in the egg shows that the stimulus to development is also present.

The arguments which have led most biologists to consider

${ }^{1}$ See the discussion in Boveri's article on Fertilization (18, pp. 403-5), and the literature there referred to. Also Guignard (23, p. I99). 


\section{4 - Sargant.-Recent Work on the Results}

the union of chromosomes as the agency by which the parental qualities are united in the offspring, are too familiar to need repetition. I need only refer to Boveri's essay on Fertilization (18, pp. 417-23) and Weismann's Germ-Plasm (45, pp. 23-35). We must consider the process of amphimixis as bound up with the act of nuclear conjugation.

It is less easy to localize the agent which carries with it the impulse to growth. In some animals it appears to reside in the centrosome belonging to the sperm-nucleus (Boveri, 13, pp. 427-9) ${ }^{1}$. Strasburger (11, p. 307) conjectures with much probability that in the higher plants the male cytoplasm may carry the growth-stimulus with it. If this be so, we have in the higher plants a compound process which it seems most convenient to call fertilization, including two subordinate processes. These are (I) amphimixis, or the union of parental qualities in the embryo, and (2) a growth-stimulus which ensures that development of this embryo shall at least begin. Fertilization thus defined is effected by the fertilizing act, which also includes two distinct phenomena-nuclear conjugation and union of the cytoplasmic constituents. There is good reason to suppose that the process of amphimixis is inseparably connected with the act of nuclear conjugation, and very possibly there may be a similar connexion between the growth-stimulus and the fusion of male cytoplasm with that of the egg-cell.

We have hitherto been considering the fertilization of the egg-cell by the male cell from the pollen-tube, the result of which is a normal embryo. Let us now apply the same touchstones to the triple fusion-often regarded as a second act of fertilization, which produces endosperm-tissue. Here we have an undoubted male nucleus fusing with two others. Of these the upper polar nucleus is the sister of the eggnucleus. It can hardly be regarded otherwise than as a female nucleus. There is in this union then, a male and a female element. Both are perfectly normal, formed by a series of reduction-divisions, and containing the reduced

${ }^{1}$ See also an article in 'Nature' for April 5, I900, p. 55 I. 
number of chromosomes. So far we have a typical sexual union. But the third element in the fusion upsets the balance. The lower polar nucleus, though originally derived from the first division of the embryo-sac nucleus, which is a reductiondivision, has since acquired a larger number of chromosomes. In Lilium Martagon, for example, the two male generative nuclei-the nucleus of the egg-cell, and the upper polar nucleus - are each built up of 12 chromosomes. The lower polar nucleus, however, is built up of at least 24 chromosomes, sometimes of more. (Guignard, 23, pp. 187-8; Sargant, 37, pp. 465 and 468.$)$

The nuclear fusion then which produces the first endospermnucleus differs from the normal conjugation of the sexual nuclei by the presence of a large mass of chromosomesubstance derived from a nucleus which shows no sexual differentiation. The fusion is certainly accompanied by a growth-stimulus, for the compound nucleus divides very rapidly.

In the sea-urchin (Boveri, 18, pp. 425-6) more than one sperm-nucleus can be forced to unite with a single egg-nucleus. Compound spindles are then formed, and the larval structures derived from the division of such ova are monstrous. It seems, however, that a normal larva is sometimes produced as a consequence of the union of two sperm-nuclei with one eggnucleus. In such a case the number of chromosomes in the nucleus of the fertilized ovum would be one-half in excess of the usual somatic number, or three times the reduced number. But the first endosperm-nucleus of Lilium Martagon contains at least twice the somatic number of chromosomes, or four times the reduced number. Many observers have noticed the large number of chromosomes characteristic of dividing nuclei in endosperm-cells.

The primary endosperm-nucleus formed by the triple nuclear fusion just discussed, gives rise on division, not to a normal embryo, which will pass through all the stages in the life-history of its species, and ultimately grow into a complete plant, but to an endosperm, which is a comparatively

$$
3 \text { A } 2
$$


small and short-lived mass of tissue. Sooner or later the endosperm is consumed by the growing embryo. Thus the result of the triple fusion differs from that of a normal act of fertilization. The organism derived from it is not a complete plant. Reproductive cells formed by a true fertilizing act are distinguished, as we have seen, by two features. They give rise to an organism which (I) passes through the complete life-history of the species to which it belongs, and (2) combines in itself some characters from both parents.

The endosperm will not stand the first test, but it has been found to satisfy the second. H. de Vries (14) and Correns $(1,2)$ have shown that when one variety of the Maize is crossed with another which differs from it in the colour or chemical constitution of its endosperm, the endosperm of the offspring commonly shows hybrid characters. Both observers believe that this is due to the presence of a male nucleus in the nuclear fusion which forms the primary endosperm-nucleus.

This view has not escaped criticism. Nawaschin (8, p. 230) supports it in a thorough-going way. He considers that these observations have conclusively shown the triple nuclear fusion to be a true act of fertilization. Correns (1), followed by Marshall Ward (15) in a summary and criticism of the subject in 'Nature,' observes that another view is possible. The embryo itself might exercise an influence on the endosperm, as, for example, by the formation of an enzyme, Strasburger (11, p. 308), though opposed to the extreme view that the triple fusion is in all essentials an act of fertilization, throws no doubt on the suggestion that the paternal characters in the hybrid endosperm are due to the presence of a male element in the nucleus from which that endosperm is derived. H. J. Webber (16) has lately published extended researches on the subject ${ }^{1}$. He finds that the endosperm does not always show hybrid characters, even though the embryo in the same embryo-sac may do so, and suggests that in such cases the second generative nucleus may not have reached the

${ }^{1}$ Dr. Webber's paper is referred to in 'Nature,' vol. 62, p. 60I. I quote from the abstract given there, as I have not seen the original. 
endosperm-nucleus at all. In other cases where the endosperm resembles the male parent in certain parts only, he supposes the second generative nucleus to have divided independently.

It would certainly be desirable to have independent evidence that the triple fusion normally takes place in Zea Mays. Until such has been obtained I think we may assume that it does so. It has been shown earlier in this paper that the mass of evidence for its general occurrence among Angiosperms is considerable. Dr. Webber's views, though quite tenable, hardly seem justified by his observations (as quoted in 'Nature'), for we know how capricious the facts of heredity appear in particular cases. The balance of probability, as of authority, seems to me to be in favour of regarding the paternal endosperm characters as derived from the presence of a male element in the primary endosperm-nucleus.

Returning to the question in hand, we have found that the nuclear fusion under consideration resembles a sexual union in containing a normal male and female element, and differs from it in including a third nucleus which in some cases is built up of at least twice as many chromosomes as either. The result of this fusion is a body which often resembles the product of fertilization in exhibiting a mixture of parental characters, but is unlike such a product in form and lifehistory. Whether we shall call such a fusion a true act of fertilization or not depends chiefly on our theoretical conception of the process of fertilization, and the definition of the act of fertilization which we choose to adopt. Authorities have already differed on this point. Before discussing the grounds on which they base their respective views, I wish to make a suggestion as to the meaning to be attached to the presence of a third nucleus.

The observations already quoted on polyspermy in the seaurchin have shown that the union of more than two nuclei in the sexual act commonly produces monstrous forms. Groom (22) has shown that fusions of two or more asexual nuclei among Fungi often led to the production of degenerate 
tissue. In the case we are considering, we have a triple fusion which unites in a single nucleus a mass of chromosomesubstance at least twice as great as that found in an ordinary somatic nucleus. The body formed by repeated division of this nucleus is small and short-lived, though from the presence of male and female elements in the combination we might almost have expected the formation of a second embryo.

It is difficult to avoid the suspicion that the presence of the third nucleus with its redundant chromosomes serves to secure the degeneracy of the resulting tissue. This hypothesis does not depend on any view as to the race-history of the fusion. If it is historically a fertilization the third nucleus may have been introduced to maim the second embryo from the beginning, and secure the survival of the first without a struggle. Its value as a food-body would secure the persistence of the abortive embryo in the shape of the tissue we call endosperm. If, on the other hand, the second generative nucleus served from the outset merely as a signal to one of the polar nuclei that fertilization had been accomplished, and that it was time for prothallial formation to proceed, the intrusion of a third nucleus would be necessary to prevent the formation of a second embryo as a consequence of the signal.

Although the question now under discussion is purely physiological, its solution would undoubtedly be forwarded by anyadvance in our knowledge concerning the origin of the triple fusion. This is another very strong reason for the investigation of anomalous embryo-sacs in the hope of hitting on primitive forms. If the first endosperm-nucleus is formed by a nuclear fusion which has once been a normal sexual union, it must now be considered as a more or less degenerate act of fertilization, and the question whether it has retained enough of its original nature to still deserve the name of fertilization is a comparatively simple one. But if such morphological research should show that Strasburger's view is justified, that the generative nucleus has never been a fertilizing agent, but has served merely as a signal for the further development of the prothallus, the process will appear in a different light. The 
resemblance to a true act of fertilization must then be considered as accidental.

Strasburger $(11$, p. 308$)$ has expressed this view with great force. It appears to him inevitable that the presence of the male element in the original nuclear fusion should affect the character of the tissue derived from it, as shown by de Vries and Correns, but he does not regard this as a proof of true ' generative fertilization,' or in other words of amphimixis. On the contrary, he proposes to classify the triple fusion among the phenomena of 'vegetative fertilization,' or, as I have hitherto called it, growth-stimulus.

It is clear that this proposal is based on a double assumption. In the first place, Strasburger considers that the endosperm is phylogenetically a prothallus, and that the nuclear fusion which gives rise to it has never been a true act of fertilization, or to use his own term a 'generative fertilization.' In the second place he believes that there is no purpose in the transference of paternal characters to the endosperm. Even if it should be proved later that such transference originally began at a time when the endosperm was clearly a second embryo, and the conjugation giving rise to it a normal act of fertilization, he believes that the process has now degenerated so far that it is physiologically a mere stimulus to growth (1. c., p. 308). On this view the presence of paternal characters in the endosperm is either an accident inseparable from the mode of stimulus which provokes its formation, or a mere survival with no physiological meaning at the present time.

We must wait for the solution of the historical question. But no one, so far as I am aware, has as yet suggested that the transference of paternal characters to the endosperm may still be of advantage to the plant. This suggestion-which seems to me of great importance-I owe to Miss Thomas, who has herself demonstrated the existence of 'double fertilization' in Caltha palustris, (Thomas, 12, 13). I am indebted to her for permission to publish her hypothesis here for the first time. 


\section{Sargant.-Recent Work on the Results}

Miss Thomas' suggestion is that in cases of cross-fertilization the endosperm formed as the result of a nuclear fusion which includes a male element - the twin-structure of the male element in the fertilized ovum-may be more suitable for the nourishment and development of the embryo arising from the same mixed stock than an endosperm formed from the mother plant alone. The food-material, for example, contained in the cells of the crossed endosperm might agree better with the crossed embryo than that supplied by an endosperm of purely maternal origin. This appears the more probable as we know that one of the characters in which de Vries and Correns traced the influence of the pollinating Maize-plant was the presence of sugar within the endosperm-cells in place of starch.

But if the endosperm is more fitted for its work by the presence of mixed characters, we must consider the phenomena of amphimixis as essential to the process of nuclear fusion which gives rise to the endosperm. In this case we can hardly refuse to regard it as now a true act of fertilization, however it may have arisen.

It appears to me possible that this view of the increased utility of the endosperm of mixed origin may partly account for the surprising effect of cross-fertilization in the first generation of plants remarked on by Darwin. He speaks of the good effects of cross-breeding as appearing much sooner in a race of plants than in one of animals. If the food supplied to the embryo is rendered more nourishing at the same time that the embryo itself gains in vigour, the effect of a cross would be doubled in a single generation.

\section{LITERATURE.}

I. Papers on Double Fertilization since I 899 :-

1. Correns: Untersuchungen über die Xenien von Zea Mays.: Ber. d. deut. bot. Gesell., 1899, p. 4 Io.

2. - Referat der Bot. Ztg., I900, p. 240.

3. Guignard, L.: Sur les anthérozoïdes et la double copulation sexuelle chez les végétaux angiospermes: Comptes rendus, Acad. d. Sci., Paris, April 4, I 899 . 
4. Guignard, L. : Les découvertes récentes sur la fécondation chez les végétaux angiospermes: Volume Jubilaire de la Société de Biologie. Paris, I 899 .

5. L'appareil sexuel et la double fécondation dans les Tulipes : Ann. des Sci. Nat., $8^{\circ}$ sér., Bot., tom. xi, I900, p. $3^{6}$.

6. Nawaschin, S. : Ref. in Bot. Centralblatt, lxxvii, p. 62, Jan. 4, I899.

7. - Resultate einer Revision der Befruchtungsvorgänge bei Lilium Martagon und Fritillaria tenella: Bull. de l'Acad. imp. des Sciences de St. Pétersb., ix, I899, p. 377 .

8. Ueber die Befruchtungsvorgänge bei einigen Dicotyledonen : Ber. d. deut. bot. Gesell., 1900, p. 224.

9. Sargant, E.: On the Presence of two Vermiform Nuclei in the Fertilized Embryo-sac of Lilium Martagon: Proc. Royal Soc., vol. lxv, p. I63.

10. Strasburger, E. : Referat in Bot. Zeit., ii, July I, I899, p. 193.

11. Einige Bemerkungen zur Frage nach der 'doppelten Befruchtung' bei den Angiospermen : Bot. Zeit., ii, Oct. I, 1900, p. 293.

12. Thomas, E. N.: On the Presence of Vermiform Nuclei in a Dicotyledon : Ann. of Bot., vol. xiv, June, I900, p. 3 I8.

13. Double Fertilization in a Dicotyledon-Caltha palustris: Ann. of Bot., vol. xiv, September, 1900, p. 577 .

14. DE VRIES, H.: Sur la fécondation hybride de l'albumen: Comptes rendus de l'Acad., Paris, Dec. 4, 1899, and in Revue générale de Bot., tom. xii, I900, p. I 29.

15. Ward, H. Marshall: Potency and Prepotency of Pollen: 'Nature,' March I 5, I900, vol. lxi, p. 470 .

16. Webber, H. J.: Xenia, or the immediate effect of Pollen in Maize : Bull. U. S. Dep. of Agricult., xxii, 1900. Washington. [Abstract and criticism in 'Nature,' Oct. I8, 1900, vol. lxii, p. 60I.]

II. Other Papers quoted :-

17. Benson, M. : Contributions to the Embryology of the Amentiferae, i: Trans. Linn. Soc., 2nd ser., Bot., vol. iii, Part I0, 1894 .

18. Boveri, O. : Befruchtung : Referat in Ergebnisse der Anatomie und Entwickelungsgeschichte. Merkel und Bonnet, 1892, p. 386 .

19. Campbell, D. H.: Notes on the Structure of the Embryo-sac in Sparganium and Lysichiton: Bot. Gaz., vol. xxvii, I899, p. I57.

20. Studies on the Flower and Embryo of Sparganium: Proc. of the California Acad. of Sc., 3rd ser., Bot., vol. i, 1899, p. 304.

21. Die Entwickelung des Embryosacks von Peperomia pellucida: Ber. d. deut. bot. Gesell., I 899, p. $45^{2}$.

22. Groom, P.: On the Fusion of Nuclei among Plants : a Hypothesis: Trans. and Proc. Bot. Soc. of Edinburgh, Sess. 63, Dec. 1898.

23. Guignard, L. : Nouvelles Études sur la Fécondation: Ann. des Sci. Nat., $7^{\ominus}$ sér., Bot., xiv, I89I.

$23 a$. Hertwig, R.: Mit welchem Recht unterscheidet man geschlechtliche und ungeschlechtliche Fortpflanzung?: Sitzungsb. d. Ges. für Morph. u. Phys. in München, I899, p. I42.

24. Hirase, S. : Untersuchungen über das Verhalten des Pollens von Ginkgo biloba.

25. Ikeno, S. : Vorläufige Mittheilung über die Spermatozoiden bei Cycas revoluta: Bot. Centralbl., lxix, 1897, p. I. 


\section{2}

Sargant.-Fertilization in Angiosperms.

26. IKENO, S. : Untersuchungen iiber die Entwickelung der Geschlechtsorgane und den Vorgang der Befruchtung bei Cycas revoluta: Jahrb. für wissensch. Bot., xxxii, Heft 4 , 1898 .

27. Johnson, D. S.: On the Endosperm and Embryo of Peperomia pellucida: Bot. Gazette, vol. xxx, I900, p. I.

28. Karsten, G.: Zur Entwickelungsgeschichte der Gattung Gnetum; Cohn's Beitr. zur Biologie d. Pfl, Bd. vi, r893, p. 337.

28 a. LANG, W. H.: Studies in the Development and Morphology of Cycadean Sporangia: II. The ovule of Stangeria paradoxa: Ann. of Bot., vol. xiv I 900.

29. Le Monnier: Sur la valeur morphologique de l'albumen chez les Angiospermes: Journ. de Bot., tom. i, I887, p. I40.

30. Lotsy, J.: Contributions to the Life-History of the genus Gnetum: Ann. du Jar. Bot. de Buitenzorg, tom. xvi, I899, p. 46.

31. Merrel, W. D. : A Contribution to the Life-History of Silphium: Bot. Gazette, xxix, 1899 .

32. 'NAture': Experimental Study of Fertilization: April 5, 1900, vol. 1xi, P. $55 \mathrm{I}$.

33. Nawaschin, S.: Zur Embryobildung der Birke: Bull. de l'Acad. imp. des Sciences de St. Pétersb., $3^{\circ}$ sér., xxxv, No. 3 .

34. Ueber die gemeine Birke . . . Mém. de l'Acad. de St. Pétersb., $7^{\ominus}$ sér., tom. xlii, I 894 .

35. Ein neues Beispiel der Chalazogamie: Bot. Centralbl., Bd. 1xiii, I 895 , p. 353 .

36. Entwickelungsgeschichte der Chalazogamen : Bull. de l'Acad. imp. des Sciences de St. Pétersb., Bd. x, I899, p. 375.

37. Sargant, E.: The Formation of the Sexual Nuclei in Lilium Martagon: Ann. of Bot., vol. $x$, r 896 , and vol. xi, 1897 .

38. Tretjakow, S.: Die Betheiligung der Antipoden in Fällen der Polyembryonie bei Allium odorum.

39. Treub, M. : Recherches sur les Cycadées : Ann. d. Jar. Bot. de Buitenzorg, 1884, vol. iv, p. I.

40. Sur les Casuarinées .... Ann. d. Jar. Bot. de Buitenzorg, tom. $\mathrm{x}, \mathrm{I} 89 \mathrm{I}$.

41. Webber, A. J.: Peculiar Structures occurring in the Pollen-Tube of Zamia: Bot. Gazette, xxiii, I 897 .

42. The Development of the Antherozoids of Zamia: Bot. Gazette, xxiv, 1897 .

43. Notes on the Fecundation of Zamia, and the Pollen-Tube Apparatus of Gingko: Bot. Gazette, xxiv, I 897 .

44. Weismann, A.: The Germ-Plasm, a Theory of Heredity : First Eng. ed., 1893 .

45. Westermaier, M. : Zur Embryologie der Phanerogamen . . . : Nova Acta d. kgl. Leop.-Carol. deut. Akad. d. Naturforscher, Bd. lvii, r 890. 


\section{$2 \mathrm{BHL}$ Biodiversity Heritage Library}

Sargant, Ethel. 1900. "Recent work on the results of fertilization in angiosperms." Annals of botany 14, 689-712. https://doi.org/10.1093/oxfordjournals.aob.a088799.

View This Item Online: https://www.biodiversitylibrary.org/item/238259

DOI: https://doi.org/10.1093/oxfordjournals.aob.a088799

Permalink: https://www.biodiversitylibrary.org/partpdf/318606

\section{Holding Institution}

Smithsonian Libraries

\section{Sponsored by}

Biodiversity Heritage Library

\section{Copyright \& Reuse}

Copyright Status: Not in copyright. The BHL knows of no copyright restrictions on this item.

This document was created from content at the Biodiversity Heritage Library, the world's largest open access digital library for biodiversity literature and archives. Visit BHL at https://www.biodiversitylibrary.org. 